\title{
Make Or Break It In SMEs Brand Building, An Empirical Study Of The Impact Of Brand Development On The Performance Of Thai SMEs.
}

\author{
Mr. Dulyathip Suntivong
}

\section{Introduction}

In every country the Small and Medium Size Enterprises (SMEs) sector is the backbone for economic development. In many parts of the world SMEs become main contributor to country's Gross Domestic Product (GDP). However, nine of every ten new businesses failed within the first two years and SMEs is a big portion of that frightening indicator. Low survival rate and lack of distinctive products amplify the chance of failure. The need for product differentiation to improve customer recognition through branding is one of the key success factors for SMEs.

By definition "Brand is a name, term, symbol, characteristic and or special design that is intended to identify the goods or services of one seller or group of sellers" and "Branding is the key to differentiate product among competitors"

From Thailand Ministry of Industry classify Small and Medium Size enterprise by mainly number of employees with less than 50 employees consider being Small enterprise and less than 200 to be Medium size enterprise. They also use other criteria such as asset value not more than 200 million Thai Baht. This research we are using number of employees because of its simplicity.

Many SMEs believed that branding is an important factor to their business success. Thai SMEs now immerging from an era of being cheap manufacturing source of International companies. The operating cost has steadily risen throughout the past 3 decades. Thai SMEs now more than ever need to develop their own brand to compete effectively in the wider market. SMEs are characterized by non-conscious brand building efforts related to the core strategy including low cost differentiation. The most successful are more proactive (Vidic \& Vadrjal, 2013). According to Centeno et al (2013) Typical SME brand building is trial and error, risk taking, involving creativity and learning? SMEs believed that branding is important factor to their success. The purpose of this study is to demonstrate relationship between branding and the impact of branding on SME impact on sales performance.

\section{Review of literatures}

There is a considerable amount of small-to-medium sized enterprises (SME) it marketing literature (Gilmore, 1999) but little of it reflects much on subject of branding in this particular field.

Sales performance is one of the measures of performance. A key reason for the focus on corporate branding in more recent years has been its documented link to improved sales performance (Madden, Fehle and Fournier, 2006). In the context of brand building in SMEs and linkage to the sales performance is not yet been explored.

Although a relationship between a strong brand identity and sales performance has yet to be established, it makes logical sense that a strong brand identity would have performance pay-offs. (Aaker, 1996) asserts that strong brands are ones which make a unique and valuable proposition which is synchronized with consumer needs. In marketing context brand is the key to differentiate product between sellers in the market. Brand can create perception of uniqueness in that product. Uniqueness of the product is displayed in several aspects such as functionality, design, value for money.

This small yet powerful concept it is very important to businesses to invest heavily on brand building activities aiming for increasing product differentiation. As a result of differentiate the product will then help increase possibility for purchase. Purchasing decision process from customer generally made by matching certain attributes of the product they intend to buy with customer's needs and experiences. The final result should be an obvious increase in SMEs sales performance compare to the competitors.

SMEs need to be more proactive and also have to express and embed their brand value propositions within their identity and reputation in their interaction with customers. Brand, reputation and brand identity need to play more active roles in offering ways of conceptualizing and documenting the realities of the contemporary business environment in which firms operates (Abimbola and Vallaster, 2007).

An earliest explicit study on SME branding is (Abimbola, 2001) who explores the role of branding as a competitive strategy. The research argues that new brands are like new products and brand extensions in 
particular need to draw on inventiveness, innovation and creative flair. Making use of the entrepreneur in public relations was also advocated (Merrilees, 2007). The paper by (Wong and Merrilees, 2005) have provided a useful typology of branding among small businesses

(Neely, 1999) confirms the importance of business performance measurement as a management imperative, he also recognizes the multitude of problems associated with the over-use of historical financial data as a single measure of performance. In today's increasingly competitive environment and with the proliferation of service based businesses, a multi-dimensional measure of performance is advocated (Neely, 1999; Venkatraman and Ramanukam, 1986). Three key dimensions are suggested: financial performance, marketing effectiveness and strategic performance (Venkatraman and Ramanukam, 1986). Financial performance relates to more objective measures of performance such as sales or profit, whilst marketing effectiveness and strategic performance are both subjective measures.

A key factor for the brand is the Founders values, identity beliefs; core competencies transmitted trough brand identity. (Spense \& Essoussi, 2010). "A brand that captures your mind gains behavior "A brand that captures your heart gains commitment" (Aker, Talgo. 2001). Brand as symbol provides cohesion and structure to an identity. Ideally, the developed characteristics are remembered each time the target sees the symbol. Brand's value proposition defines as, a statement of the functional, emotional and self-expressive benefits delivered by the brand that provide value to the customer.

Ogilvy suggests an approach called Express Brand Identity. This is an easy step-by-step development:

1. Leverage strengths through core value

2. Innovation

3. Using the Brand for competitive advantage (Ward, 2012).

However, most SMEs do not focus on Brand identity. They do not formally develop Brand Building activities including CRM and emphasizing Brand Identity. For those that do, higher annual turnover is the most important factor in brand building (Hirvonen \& LaukKanen, 2011).

Searching for brand identity is a starting point of brand building activity. Most effective way to search for brand identity for an entrepreneur is to allies brand identity of the company to their own believes. By conveying message about SME owner personal values and translate them into corporate value. For SME there is an important role of brand management with an internal passion for the brand and an active role of entrepreneur (Krake, 2005).

Brand identity is the unique set of brand associations that establishes a relationship with the target audiences. (Aker, 2001) These associations generate value via functional, emotional or self-expressive benefits. The brand is more than the tangible product itself; it also is a collection of these other important relational variables. There is also little research on the relationship of Brand Building and SME performance. A recent study found size and age dominate performance. (Blackburn et al, 2013).

Impact on organizational performance will have a positive relationship with brand identity representing by the norms and beliefs of the owners (Deshpande and Webster, 1989). However, still very limited research has examined the link between corporate culture and brand identity. Brand identity will have a positive relationship with organizational performance. The importance of branding as a point of differentiation and a source of positional advantage is well recognized by product oriented organizations. However cultural and recreational services also face increasing competition and their inherent intangibility, variability and perish ability suggest that a strong brand would be even more important than for product based firms.

\section{Methodology and data collection}

Starting from an effort to try to explain relationships between phenomena by focusing on certain set of variables and identify whether one is dependent variable or independent from the rest. For each variables researcher also need to define unit of measures to be able to quantify the strength and direction of a relationship. This direction and strength of a relationship will help us come to the conclusion and answer previously set research questions.

In the research will use survey by questionnaire as primary data collection tool. The survey will consisted of three main sections and comprised of several questions related to branding and impact on branding. Survey questions will be answer by SME owners, managers and representative.

During the process of formulating questions on the survey the researcher went through many literatures and list out several variables. At the beginning research interviewed 6 SMEs owners in various industries to define which questions relevant to their brand building. The interview answers then use in the smaller analysis to test for the reliability and validity of the questions asked. In total the researcher has 33 variables that identified as significant to the SMEs brand building and converted them into survey questions. In addition to the answers given the research also gain insight information from the interview on how they see their respective company compare with their competitors. How brand building activities can be effectively improve their sales performance. 
The 6 SMEs are

- $\quad$ Raming Tea Company (Foods and Agriculture) 150 employees

- $\quad$ Cotton Farm (Handy Craft) 45 employees

- $\quad$ Exza Celam (Dental Supplies and Dental Equipment) 164 employees

- $\quad$ Pacific Biotech (Foods and Food Supplements) 146 employees

- $\quad$ Bangkok RIA (Medical Laboratory Service) 200 employees

- $\quad$ Raja Cycle (Bicycle manufacture with 2 separate bike brands) 180 employees

The survey questions from the initial review of literature, interview and testing then distributed to wide variety of SMEs owners and managers here in Thailand as primary data collection process. The research targeted 240 samples from 3 SMEs categories, which are production, service and technology, agriculture and foods. There are 177 actual questionnaires returned to the researcher and 126 can be use with completed data ready for secondary data collection. From database of Thai SME from Thailand local bank, the researcher takes advantage of the periodic gathering of SME customers at the local bank headquarter for networking activity and seminar. This gather will include SMEs from all industry from all region of Thailand at around 30-40 participants each time.

Secondary data collection will come from the company register name that the surveyors given. The use of accessing sale data from year 2009-2011 from an audited financial statement submitted to "The Department of Business Development Thai Ministry of Commerce" is free and open to public. Once the sale performance information has been collected the researcher will use figures from 2009-2011 to find the average sales performance.

Research then make a comparative analysis with in the selected samples and separate them into two groups. By selecting SMEs with good performance and compare the survey results with the rest (average performance). Then establish relationship from their answers regarding branding activity. Research expecting the result to be positive correlation with better performs SMEs put more effort and priority into their brand and brand management.

\section{Analysis and results}

After data secondary data collection the research began to analyze the data set of 126 surveys. In the analyzing process will include reliability analysis, factor analysis and the researcher using regression analysis to explain the relationship between the dependent variable "sales performance" and factors related to the branding answered by SMEs. The first item is reliability testing result by calculating Crombach's alpha from sample set and expect result to be higher than 0.7. As a result the reliability for (Brand building activities is .890, CRM is .825 and Brand identity .845 and .884 ). From this result we can concluded that the survey questions are reliable. Reliability Test (Cronbach's Alpha)

Brand Building Activities

Reliability Statistics

\begin{tabular}{|l|l|l|}
\hline Cronbach's Alpha & $\begin{array}{l}\text { Cronbach's Alpha Based on } \\
\text { Standardized Items }\end{array}$ & N of Items \\
\hline .889 & .890 & 15 \\
\hline
\end{tabular}

CRM

Reliability Statistics

\begin{tabular}{|l|l|l|}
\hline Cronbach's Alpha & $\begin{array}{l}\text { Cronbach's Alpha Based on } \\
\text { Standardized Items }\end{array}$ & N of Items \\
\hline .812 & .825 & 8 \\
\hline
\end{tabular}

Brand Identity Functional

Reliability Statistics

\begin{tabular}{|l|l|l|}
\hline Cronbach's Alpha & $\begin{array}{l}\text { Cronbach's Alpha Based on } \\
\text { Standardized Items }\end{array}$ & N of Items \\
\hline .873 & .875 & 5 \\
\hline
\end{tabular}

Brand Identity Symbolic

Reliability Statistics

\begin{tabular}{|l|l|l|}
\hline Cronbach's Alpha & $\begin{array}{l}\text { Cronbach's Alpha Based on } \\
\text { Standardized Items }\end{array}$ & N of Items \\
\hline .877 & .884 & 5 \\
\hline
\end{tabular}

In the case of testing for validity with two main tests the First one is face validity. Focus of this research on Thai SME in all 3 types of SME Manufacturing, Trading and Service. Due to geographic limitation of sample size only for Thailand and all SMEs selected within the criteria classified by Ministry of Industry. The 
local bank database covers all aspects of SMEs whom already passed the start up period and entering the phase of expansion. This provides the face validity of 126 samples selected in this research.

For construct validity will be tested by calculating Eigen's value to be higher than 0.5 from the factor analysis process. This will ensure new factors generated from 33 variables (questions on the survey) are indeed valid. From the factory analysis and the extraction for Eigen's value 7 new factors are formed from 33 questions. Band Building Activities have 3 new factors, CRM have 2 new factors and Brand identity have 2 new factors one for Functional Identity and one for Symbolic Identity.

Eigen Values higher than 0.5. Three new factors generated

1. F1BBA : Documented, Logo, Team involvement, Planning, Budgeting and Decision Making

2. F2BBA : Brand Portfolio, Brand Extension, Advertising, PR and Trade Show

3. F3BBA : Online Marketing, Uniform and Internal communication

\begin{tabular}{|c|c|c|c|}
\hline & \multicolumn{3}{|c|}{ Component } \\
\hline & 1 & 2 & 3 \\
\hline Documented & .745 & .119 & .002 \\
\hline Logo & .743 & .142 & .248 \\
\hline team involvement & .759 & .087 & .038 \\
\hline Brands portfolio & .168 & .672 & -.047 \\
\hline brand Extension & .382 & .717 & .044 \\
\hline communication channels & .158 & .249 & .398 \\
\hline Advertising & .060 & .636 & .495 \\
\hline Public relations & .054 & .656 & .550 \\
\hline Tradeshow & .163 & .587 & .421 \\
\hline Online marketing & .085 & .358 & 640 \\
\hline Uniforms & .108 & -.132 & .776 \\
\hline internal communication & .547 & .130 & .592 \\
\hline Planning & .440 & .369 & .467 \\
\hline Budgeting & .582 & .373 & .390 \\
\hline Decision & .568 & .382 & .351 \\
\hline
\end{tabular}

Extraction Method: Principal Component Analysis.

Rotation Method: Varimax with Kaiser Normalization.

CRM

a. Rotation converged in 6 iterations.

Eigen Values higher than 0.5. Two new factors generated

4. F4 CRM : 7 variables included in this factor

5. F5 CRM : Brand Ambassador

Component Matrix ${ }^{a}$

\begin{tabular}{|l|l|l|}
\hline \multirow{2}{*}{} & \multicolumn{2}{l|}{ Component } \\
\cline { 2 - 3 } & 1 & 2 \\
\hline customer information & .634 & -.437 \\
Organize & .663 & -.502 \\
Newsletter & .577 & .395 \\
brand ambassadors & .543 & .702 \\
Training & .736 & .254 \\
customer knowledge and experience & .805 & .066 \\
information exchange & .791 & -.081 \\
extent customer & .607 & -.289 \\
\hline
\end{tabular}

Extraction Method: Principal Component Analysis.

a. 2 components extracted.

Brand Identity (Functional)

Eigen Values higher than 0.5. One new factor generated which included all variables

6. F6 BIF: 5 variables included in this factor 
Brand Identity (Symbolic)

\begin{tabular}{|l|l|}
\hline \multirow{2}{*}{} & Component \\
\cline { 2 - 2 } & 1 \\
\hline served the functional purpose & .761 \\
Provided & .860 \\
Efficiency & .879 \\
Innovative & .773 \\
Expertise & .809 \\
\hline
\end{tabular}

Extraction Method: Principal Component Analysis.

a. 1 components extracted.

Eigen Values higher than 0.5. One new factor generated which included all variables

7. F7 BIS: 5 variables included in this factor

Component Matrix ${ }^{\mathrm{a}}$

\begin{tabular}{l|l|}
\hline & Component \\
\cline { 2 - 2 } & 1 \\
\hline origin prestige & .770 \\
suitable with lifestyle & .861 \\
Uniqueness & .877 \\
Credibility & .853 \\
SMEs CSR & .768 \\
\hline Extraction Method: Principal Component \\
Analysis. \\
a. 1 components extracted.
\end{tabular}

After testing result shows that the 126 samples collected are valid and reliable the research continues with the data analysis. The method used in this research is regression analysis which is a statistical process for estimating the relationships among variables. It includes many techniques for analyzing several variables when the focus is on the relationship between a dependent variable and one or more independent variables. The researcher tries 3 different models. First two models are using percentage of sale growth from year 2009-2011 and third model is using the average 3 years sale figure.

After reviewing the Regression Summary, the first two models relate to Sales Growth. Model I considers the Brand Building Actions, CRM and Brand Identity. These variables explain $10.5 \%$ of Sales Growth but does not achieve the level of significance of .05 Model 2 adds the Background Characteristics, position, type of business 15 years of operation and Number of Employees. Over 5 years of operation indicates survival. The number of employees relates to size. This combination of variables explains $17 \%$ of the sales growth. It is significant.

Two variables have significant betas but they are negative. Brand Ambassadors (CRM2) has a beta of .212 and survival has a beta of -.219 .

The implications of these results are as the SME emphasizes more personalized customer relationships, it has lower Sales Growth. As the SME achieves longer duration sales growth goes down.

Regression Summary

\begin{tabular}{|l|l|l|}
\hline Model 1 & Model 2 & Model 3 \\
\hline D.V. \% Growth & D.V. \% Growth & D.V. Average Sales \\
\hline $\mathrm{R}^{2} 10.5 \%(.06)$ & $\mathrm{R}^{2} 16.6 \%(.02)$ & $\mathrm{R}^{2} 39.9 \%(.01)$ \\
\hline & Betas & Betas \\
\hline & CRM2 -.212 (.04) & BBA1 -.278 (.008) \\
\hline & $5^{\text {th }}$ year $-.219(.02)$ & BBA2 -.270 (.01) \\
\hline & & CRM2 -.153 (.09) \\
\hline & & $5^{\text {th }}$ year $.252(.002)$ \\
\hline & & \# Employees $.393(.001)$ \\
\hline
\end{tabular}

Model 3 examines average sales over 3 years as the dependent variable. In this model the Brand Building Activities, CRM and Brand Identity are included with the Background Characteristics. This combination significantly explains $40 \%$ of the Average Sales.

Four variables have significant betas. Two are related to Brand Building. These are Brand process (.278) which is negative and Brand portfolio (.270) which is positive. The more an SME emphasizes the process, the lower are the Average Sales, but if the activities concentrate on a brand portfolio the higher than Average 
Sales will be. The remaining variables are Background Characteristics. The longer an SME survives and the larger it is increases Sales Performance.

From the total of 126 samples the researcher also come up with another observation from basic descriptive statistic of the data. By using mean performance from percentage of sale growth with ranking of the answers given in the survey to indicate the effort in certain area of brand building. The researcher found that top ten best brand building activities that out perform the mean sales growths of $19.75 \%$ are

\begin{tabular}{|l|l|l|}
\hline Ranking & Description & $\%$ \\
\hline 1 & Team Involvement & 11.79 \\
2 & Providing needs & 11.41 \\
3 & Serve Functional Purpose & 9.90 \\
4 & Efficiency & 9.69 \\
5 & Documentation & 9.57 \\
6 & Creditability & 9.15 \\
7 & Organize Info & 8.23 \\
8 & Logo & 8.18 \\
9 & Public Relation & 7.07 \\
10 & Internal Communication & 6.96 \\
\hline
\end{tabular}

\section{Conclusion and Discussion}

From the beginning the goal of this research always been to find evidence to support the relationships and measures the impact of branding in Thai SME context. The research result shows that branding is an important aspect of SME business operation. Branding directly effect SME sale performance but different items from the list of variables related to branding have different degree of impact.

This research provided first empirical evidence to support the conclusion that identifies relationship between branding and sales performance of SME. The relationship is $39.9 \%$ of sales performance can be explained by branding and SMEs basic background characteristics. The research clearly quantify each variables with and their impact despite some beliefs that predate this research the result clearly link more internal brand building better that external activities.

This research has originality in two main areas, 1. The research included all sectors of SMEs and 2. The research has evidence to support the measurement of impact on SMEs branding. There is a shortage of empirical evidence that branding can impact sales performance. With this new evidence from the research result we can now concluded that branding surely will have positive impact on the SMEs sales performance in Thailand.

As a result, the contribution to the Branding field of study is enhancing the understanding of Brand impact on smaller companies in SME environment such as Thailand. How it differs from the branding impact in the context of large corporation that often measure brand using brand equity value. In SMEs context brand equity still doesn't exist, this research shows branding still have positive impact and explain a lot of sales performance in smaller company that do not have brand equity. The most important contribution is the ability to quantify for the first time the branding impact on SMEs.

More than $80 \%$ of business in Thailand is SME and their survival is important to overall economic livelihood of the country. I started planning to embark on this research the research fully aware of its significance in helping Thai SME. SME limited resource more effectively in branding process. Research finding can immediately help SME owners and managements to make decision referring to the impact percentage that each activity (variable) can produce above the Thai SMEs average performance. They can get the most value by selecting appropriate variables that suit them well in their own business operation.

This careful selection will help enhance utilizing their resource to the maximum with little waste. SMEs in Thailand are bombarded by fancy marketing terms and from this point onward they will know the benchmark on what branding result will be in their business when they decided to invest in such activity.

Limits and future research

The research only done in Thailand based on Thai SMEs and the result cannot explain the same phenomenon in other countries until similar research has been done. Secondly as many researches related to SMEs one major problem facing primary data collection is SMEs data is one of the hardest things to find. They are operating in all sorts of locations. They are difficult to reach and they also did not have a lot of historical data kept in such an organized manner. 


\section{References}

[1]. Blackburn, R. et al (2013). "Small Business Performance, Business Strategy and Owner Manager Characteristics". Journal of Small Business and Enterprise Development, 20:1, 8-27.

[2]. Centeno, E. et al (2013). "The Five Phases of SME Brand Building”. Journal of Brand Management, 20, 445-457. Gabriel, L. Copy of Thai SMEs Brand Building.

[3]. Harrigan, P. et al (2011). "Exploring and Explaining SME Marketing”. Journal of Strategic Marketing, 20:2, $127-163$.

[4]. E CRM enables customer communication and information capabilities.

[5]. Gill, A. \& N. Biger (2012). "Barriers to Small Business Growth on Canada". Journal of Small Business and Enterprise Development, 19:4, 656-668.

[6]. Sales level positive for growth

[7]. Hirvonen, S. \& T. Laukkanen (2011). "Branding in Small Firms: Are All SMEs Similar?" ANLMAC Conference.

[8]. Krake, F. (2005). "Successful Brand Management in SMEs". Journal of Product and Brand Management, $228-238$.

[9]. Odonnell, A. (2011). "Small Firm Marketing Synthesizing and Supporting Received Wisdom". Journal of Small Business and Enterprise Development, 18:4, 781-805.

[10]. Parry, S. et al (2012). "Marketing for Survival A Comparative Study of SME Software Firms". Journal of Small Business and Enterprise Development, 19:4, 712-719.

[11]. Customer relations and delivering on the promise

[12]. Reijonen, H. (2010). "Do All SMEs Practice the same Kind of Marketing". Journal of Small Business and Enterprise Development, $17: 2,279-293$.

[13]. Main focus creating and maintaining customer relationship.

[14]. Spence, M. \& L. Essoassi (2010). “SME Brand Building and Management: An Exploratory Study". E Journal Marketing, 44:7/8, $1037-1054$.

[15]. Vidic, F. \& J. Vadnjal (2013). “The Role of Branding in SMEs”. China USA Business Review, 12:1, 79-88.

[16]. Ward, E. (2012). "Brand Building is the key to Enhancing an SMEs Competitiveness and Profitability".

[17]. Olgory on SMEs Academia education

[18]. Alba, Joseph W. and J. Wesley Hutchinson (1987), "Dimensions of Consumer Expertise", Journal of Consumer Research, March, Page 411-453

[19]. Asian Development Bank (2007), Industrial Competitive Survey.

[20]. Barry, Leonard L. (2000), "Cultivating Service Brand Equity”, Journal of the Academic of Marketing Science. Volume 28, Page 128-137

[21]. Fazio, Russell H. (1987), "Category-Brand Associations and Their Activation from Memory”, Unpublished Report Ogilvy Center for Research and Development, San Francisco CA.

[22]. Hassler Markus (2003), "Crisis, coincidences and strategic market behavior: the internationalization of Indonesian Clothing brandowners", Royal Geographical Society Institute, May, Page 241-250

[23]. Hollis N. (2008), "Five brand success factors", the global brand online.com

[24]. Keller, K.L. (1993), "Conceptualizing, measuring, and managing customer-based brand equity", Journal of Marketing, January, Page 1-22

[25]. Kerner, Noah (2007), "Share Equity, Win Authenticity", Advertising Age Chicago, April Vol. 78, Page 26

[26]. Kotler, Phillip H. (1991), Marketing Management: Analysis, Planning and Control, 8th ed. Prentice-Hall Inc.

[27]. Myers, James H. and Allan D. Shocker (1981), “The Nature of Product Related Attributes", Research in Marketing Vol.5, JAI Press Inc. Page 211-236

[28]. O’Neal, Mike (2008), “The Value of Brands", Dealer-scope, May, Page 72

[29]. Park, Chan-Su (1991), "Estimation and Prediction of Brand Equity Through Survey Measurement of Consumer Preference Structure", Unpublished Doctoral Dissertation, Graduate School of Business, Stanford University.

[31]. Srull Thomas K. (1984), "Methodological Techniques for Study of Person Memory and Social Cognition", Hand Book of Social Cognition Vol.2, Erlbaum Associates, Page 1-72

[32]. Tauber, Edward M. (1988) "Brand Leverage: Strategy for Growth in a Cost Controlled World", Journal of Advertising Research, August-September, Page 26-30.

[33]. Asian Development Bank Website: www.adb.org

[34]. Thai SME Bank Website: www.smebank.co.th

[35]. Institution of Thai SME Development Website: www.theglobalbrandonline.com

[36]. Spence Martine and Essoussi Hamzaoui (2010), "SME brand building and management: an exploratory study", European Journal of Marketing, Vol 44, Page 1037-1054

[37]. Becker Jan, Greve Goetz and Albers Sonke (2009), "The impact of technological and organizational implementation of CRM on customer acquisition, maintenance and retention", International Journal of Research in Marketing, Vol 26, Page 207-215

[38]. Taticchi Paolo, Tonelli Flavio and Cagnazzo Luca (2011), "Development of a Performance Measurement System: Case study of an Italian SME"

[39]. Hagg Gustav and Jonsson Niklas (2010), "Brand building activities in Small Service Firms: A Qualitative study on Swedish Rea Estate Firms"

[40]. Gilmore Francis (2002), “A Country can repositioned?”, The Journal of Brand Management, Vol 9, Page 281-293

[41]. Madden Thomas, Fehle Frank and Fournier Susan (2006), "Brands matter: An Empirical investigation of brand building activities and the creation of shareholder value", Harvard Business Review

[42]. Aaker David (1996), "Measuring brand equity across products and markets", California Management Review, Vol 38 Page 102121.

[43]. Aaker David (2001), "The value relevance of brand attitude in High Technology Markets", Journal of marketing research, Vol 38 Page 485-493

[44]. Abimbola Temi (2001), "Branding as a competitive strategy for Demand Management in SMEs", Journal of research in marketing and entrepreneurship, Vol 3 Page 97-106

[45]. Abimbola Temi, Vallaster Christine (2007). "Brand, Orgainzation Identity and Reputation in SMEs", Qualitative market research An International Journal", Vol 10 Page 341-348

[46]. Merrilees Bill (2007), "A theory of brand-led SME new venture development", Qualitative market research An International Journal", Vol 10 Page 403-415

[47]. Merrilees Bill and Wong Ho Yin (2005). "A brand orientation typology for SME", Journal of product and brand management", Vol 14 Page 155-162 
[48]. Neely Andy (1999), "Measuring performance in changing business environment", International Journal of Operations and Production Management”, Vol 23 Page 213-229

[49]. Desphade Rohit and Webster Frederick (1989), “Organizational Culture and Marketing”, American Marketing Association Journal, Vol 53 Page 3-15

Tables for regression analysis

Variables Entered/Removed ${ }^{\mathrm{b}}$

\begin{tabular}{|l|lr|l|l|}
\hline Model & Variables Entered & Variables Removed & Method \\
\hline 1 & F7BIS, & F5CRM, \\
& F4CRM, & F2BBA, & & \\
& F6BIF, & F1BBA, & & Enter \\
& F3BBA & & \\
\hline
\end{tabular}

a. All requested variables entered.

b. Dependent Variable: Performance

Model Summary

\begin{tabular}{|l|l|l|l|l|}
\hline Model & $\mathrm{R}$ & R Square & Adjusted R Square & $\begin{array}{l}\text { Std. Error of the } \\
\text { Estimate }\end{array}$ \\
\hline 1 & $.325^{\mathrm{a}}$ & .105 & .052 & 41.84994 \\
\hline
\end{tabular}

a. Predictors: (Constant), F7BIS, F5CRM, F4CRM, F2BBA, F6BIF, F1BBA, F3BBA

ANOVA $^{\mathrm{b}}$

\begin{tabular}{|ll|l|l|l|l|l|}
\hline Model & & Sum of Squares & Df & Mean Square & F & Sig. \\
\hline 1 & Regression & 24352.601 & 7 & 3478.943 & 1.986 & $.063^{\mathrm{a}}$ \\
& Residual & 206667.268 & 118 & 1751.418 & & \\
& Total & 231019.869 & 125 & & & \\
\hline
\end{tabular}

a. Predictors: (Constant), F7BIS, F5CRM, F4CRM, F2BBA, F6BIF, F1BBA, F3BBA

b. Dependent Variable: Performance

\begin{tabular}{|c|c|c|c|c|c|c|c|c|}
\hline \multicolumn{9}{|c|}{ Coefficients $^{\mathbf{a}}$} \\
\hline \multirow{2}{*}{\multicolumn{2}{|c|}{ Model }} & \multicolumn{2}{|c|}{$\begin{array}{l}\text { Unstandardized } \\
\text { Coefficients }\end{array}$} & \multirow{2}{*}{$\begin{array}{l}\text { Standardized } \\
\text { Coefficients } \\
\text { Beta }\end{array}$} & \multirow[t]{2}{*}{$\mathrm{T}$} & \multirow[t]{2}{*}{ Sig. } & \multicolumn{2}{|c|}{$95 \%$ Confidence Interval for B } \\
\hline & & $\mathrm{B}$ & Std. Error & & & & Lower Bound & $\begin{array}{l}\text { Upper } \\
\text { Bound }\end{array}$ \\
\hline \multirow[t]{8}{*}{1} & (Constant) & -63.419 & 29.796 & & -2.128 & .035 & -122.423 & -4.414 \\
\hline & F1BBA & 2.206 & 7.462 & .036 & .296 & .768 & -12.571 & 16.983 \\
\hline & F2BBA & 5.601 & 6.751 & .103 & .830 & .408 & -7.768 & 18.970 \\
\hline & F3BBA & 8.314 & 6.305 & .160 & 1.319 & .190 & -4.171 & 20.799 \\
\hline & F4CRM & 9.057 & 8.964 & .119 & 1.010 & .314 & -8.694 & 26.809 \\
\hline & F5CRM & -7.505 & 3.960 & -.203 & -1.895 & .060 & -15.346 & .336 \\
\hline & F6BIF & 8.210 & 6.708 & .141 & 1.224 & .223 & -5.075 & 21.494 \\
\hline & F7BIS & -6.084 & 4.808 & -.136 & -1.265 & .208 & -15.605 & 3.437 \\
\hline \multicolumn{4}{|c|}{ a. Dependent Variable: Performance } & & & & & \\
\hline
\end{tabular}

Variables Entered/Removed ${ }^{\text {b }}$
\begin{tabular}{|l|l|l|l|}
\hline Model & Variables Entered & Variables Removed & Method \\
\hline 1 & Q6employees, & & \\
& F4CRM, & & \\
& Q4TBusiness, & & Enter \\
& Q3Position, Q5Year, & & \\
& F7BIS, F5CRM, & & \\
& F2BBA, F6BIF, & & \\
& F1BBA, F3BBA & & \\
\hline
\end{tabular}

a. All requested variables entered.

b. Dependent Variable: Performance

Model Summary
\begin{tabular}{|l|l|l|l|l|}
\hline Model & $\mathrm{R}$ & R Square & Adjusted R Square & $\begin{array}{l}\text { Std. Error of the } \\
\text { Estimate }\end{array}$ \\
\hline 1 & $.408^{\mathrm{a}}$ & .166 & .086 & 41.10841 \\
\hline
\end{tabular}




Model Summary
\begin{tabular}{|l|l|l|l|l|}
\hline Model & R & R Square & Adjusted R Square & $\begin{array}{l}\text { Std. Error of the } \\
\text { Estimate }\end{array}$ \\
\hline 1 & $.408^{\mathrm{a}}$ & .166 & .086 & 41.10841 \\
\hline
\end{tabular}

a. Predictors: (Constant), Q6employees, F4CRM, Q4TBusiness, Q3Position, Q5Year, F7BIS, F5CRM, F2BBA, F6BIF, F1BBA, F3BBA

ANOVA $^{\mathrm{b}}$

\begin{tabular}{|ll|l|l|l|l|l|}
\hline Model & & Sum of Squares & Df & Mean Square & F & Sig. \\
\hline 1 & Regression & 38371.126 & 11 & 3488.284 & 2.064 & $.029^{\mathrm{a}}$ \\
& Residual & 192648.743 & 114 & 1689.901 & & \\
& Total & 231019.869 & 125 & & & \\
\hline
\end{tabular}

a. Predictors: (Constant), Q6employees, F4CRM, Q4TBusiness, Q3Position, Q5Year, F7BIS, F5CRM, F2BBA, F6BIF, F1BBA, F3BBA

b. Dependent Variable: Performance

Coefficients $^{\mathrm{a}}$

\begin{tabular}{|c|c|c|c|c|c|c|c|c|}
\hline & & \multicolumn{2}{|c|}{ Unstandardized Coefficients } & \multirow{2}{*}{\begin{tabular}{|l} 
Standardized \\
Coefficients
\end{tabular}} & \multirow[b]{2}{*}{$\mathrm{T}$} & \multirow[b]{2}{*}{ Sig. } & \multicolumn{2}{|c|}{$95 \%$ Confidence Interval for B } \\
\hline \multicolumn{2}{|c|}{ Model } & B & Std. Error & & & & Lower Bound & Upper Bound \\
\hline \multirow[t]{12}{*}{1} & (Constant) & -50.371 & 32.907 & & -1.531 & .129 & -115.560 & 14.819 \\
\hline & F1BBA & 5.513 & 7.442 & .090 & .741 & .460 & -9.231 & 20.256 \\
\hline & F2BBA & 3.777 & 6.736 & .069 & .561 & .576 & -9.567 & 17.121 \\
\hline & F3BBA & 8.856 & 6.295 & .170 & 1.407 & .162 & -3.613 & 21.326 \\
\hline & F4CRM & 6.290 & 9.385 & .083 & .670 & .504 & -12.302 & 24.882 \\
\hline & F5CRM & -7.820 & 3.925 & -.212 & -1.992 & .049 & -15.596 & -.043 \\
\hline & F6BIF & 6.372 & 6.737 & .109 & .946 & .346 & -6.974 & 19.718 \\
\hline & F7BIS & -7.359 & 4.796 & -.164 & -1.534 & .128 & -16.860 & 2.142 \\
\hline & Q3Position & 2.817 & 4.670 & .055 & .603 & .548 & -6.434 & 12.068 \\
\hline & Q4TBusiness & 3.670 & 2.439 & .135 & 1.505 & .135 & -1.162 & 8.502 \\
\hline & Q5Year & -.820 & .362 & -.219 & -2.264 & .025 & -1.538 & -.103 \\
\hline & Q6employees & $-7.846 \mathrm{E}-5$ & .014 & .000 & -.006 & .996 & -.028 & .028 \\
\hline
\end{tabular}

a. Dependent Variable: Performance

Variables Entered/Removed

\begin{tabular}{|c|c|c|c|}
\hline Model & $\begin{array}{l}\text { Variables } \\
\text { Entered }\end{array}$ & $\begin{array}{l}\text { Variables } \\
\text { Removed }\end{array}$ & Method \\
\hline 1 & $\begin{array}{l}\text { Q6employees, } \\
\text { F4CRM, } \\
\text { Q4TBusiness, } \\
\text { Q3Position, } \\
\text { Q5Year, F7BIS, } \\
\text { F5CRM, } \\
\text { F2BBA, F6BIF, } \\
\text { F1BBA, } \\
\text { F3BBAa }\end{array}$ & . & Enter \\
\hline
\end{tabular}

a. All requested variables entered.

b. Dependent Variable: Average 3 years sales

Model Summary

\begin{tabular}{|l|l|l|l|l|}
\hline Model & $R$ & R Square & $\begin{array}{l}\text { Adjusted R } \\
\text { Square }\end{array}$ & $\begin{array}{l}\text { Std. Error of the } \\
\text { Estimate }\end{array}$ \\
\hline 1 & $.632 \mathrm{a}$ & .399 & .341 & $8.67588 \mathrm{E} 7$ \\
\hline
\end{tabular}


a. Predictors: (Constant), Q6employees, F4CRM, Q4TBusiness,

Q3Position, Q5Year, F7BIS, F5CRM, F2BBA, F6BIF, F1BBA,

F3BBA

ANOVAs

\begin{tabular}{|c|c|c|c|c|c|c|}
\hline \multicolumn{2}{|c|}{ Model } & Sum of Squares & df & Mean Square & $\mathrm{F}$ & Sig. \\
\hline \multirow[t]{3}{*}{1} & Regression & $569,808,625,096,275,200$ & 11 & $\begin{array}{l}51,800,784,099, \\
661,384\end{array}$ & \multirow[t]{3}{*}{6.882} & \multirow[t]{3}{*}{$.000 \mathrm{a}$} \\
\hline & Residual & $858,087,249,240,031,740$ & 114 & $\begin{array}{l}7,527,081,133,6 \\
84,489\end{array}$ & & \\
\hline & Total & $1,427,895,874,336,306,940$ & 125 & & & \\
\hline
\end{tabular}

a. Predictors: (Constant), Q6employees, F4CRM, Q4TBusiness, Q3Position, Q5Year, F7BIS, F5CRM, F2BBA, F6BIF, F1BBA, F3BBA

b. Dependent Variable: Average 3 years sales

\begin{tabular}{|c|c|c|c|c|c|c|c|c|}
\hline \multicolumn{9}{|c|}{ Coefficients } \\
\hline & & \multicolumn{2}{|c|}{ Unstandardized Coefficients } & \multirow{2}{*}{\begin{tabular}{|l|}
$\begin{array}{l}\text { Standardized } \\
\text { Coefficients }\end{array}$ \\
Beta \\
\end{tabular}} & \multirow[b]{2}{*}{$\mathrm{t}$} & \multirow[b]{2}{*}{ Sig. } & \multicolumn{2}{|c|}{$95 \%$ Confidence Interval for B } \\
\hline \multicolumn{2}{|c|}{ Model } & B & Std. Error & & & & Lower Bound & Upper Bound \\
\hline 1 & (Constant) & $-68,361,836$ & $69,450,520$ & & -.984 & .327 & $-2.059 \mathrm{E} 8$ & $6.922 \mathrm{E} 7$ \\
\hline & F1BBA & $-4.248 \mathrm{E} 7$ & $15,706,967$ & -.278 & -2.704 & .008 & $-7.359 \mathrm{E} 7$ & $-1.136 \mathrm{E} 7$ \\
\hline & F2BBA & $3.664 \mathrm{E} 7$ & $14,216,256$ & .270 & 2.577 & .011 & 8479305.297 & $6.480 \mathrm{E} 7$ \\
\hline & F3BBA & 713521.199 & $13,285,034$ & .006 & .054 & .957 & $-2.560 \mathrm{E} 7$ & $2.703 \mathrm{E} 7$ \\
\hline & F4CRM & 3260855.246 & $19,807,351$ & .017 & .165 & .870 & $-3.598 \mathrm{E} 7$ & $4.250 \mathrm{E} 7$ \\
\hline & F5CRM & $-1.409 \mathrm{E} 7$ & $8,284,628$ & -.153 & -1.701 & .092 & $-3.050 \mathrm{E} 7$ & 2319612.648 \\
\hline & F6BIF & $2.989 \mathrm{E} 7$ & $14,218,095$ & .206 & 2.102 & .038 & 1727304.115 & $5.806 \mathrm{E} 7$ \\
\hline & F7BIS & 8350669.048 & $10,122,151$ & .075 & .825 & .411 & $-1.170 \mathrm{E} 7$ & $2.840 \mathrm{E} 7$ \\
\hline & Q3Position & 8167183.358 & $9,856,060$ & .064 & .829 & .409 & $-1.136 \mathrm{E} 7$ & $2.769 \mathrm{E} 7$ \\
\hline & Q4TBusiness & -3010431.659 & $5,147,498$ & -.045 & -.585 & .560 & $-1.321 \mathrm{E} 7$ & 7186722.064 \\
\hline & Q5Year & 2346863.949 & 764,544 & .252 & 3.070 & .003 & 832307.496 & 3861420.401 \\
\hline & Q6employees & 147438.258 & 29,673 & .393 & 4.969 & .000 & 88656.246 & 206220.269 \\
\hline
\end{tabular}

a. Dependent Variable: Average 3 years sales 